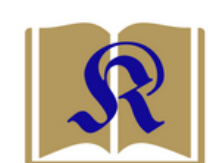

KURIOS
KURIOS

(Jurnal Teologi dan Pendidikan Agama Kristen)

ISSN 2615-739X (print), 2614-3135 (online)

Vol. 5, No. 2, Oktober 2019 (175-189)

http://www.sttpb.ac.id/e-journal/index.php/kurios

\title{
Menerapkan Model Penginjilan pada Masa Kini
}

\author{
Hannas $^{1}$, Rinawaty ${ }^{2}$ \\ ${ }^{1,2}$ Sekolah Tinggi Teologi Harvest Internastional Jakarta \\ hannas@hits.ac.id
}

\begin{abstract}
Evangelism has many obstacles, it cannot be done optimally, the challenges faced cannot weaken the spirit of winning souls for Jesus Christ. That is why it is necessary to try to develop the right evangelistic model. This study found 6 (six) evangelistic models, namely: interpersonal, personal, mass, media services, social services and friendship. The research method used is qualitative with the approach phenomenology. In conclusion, the preaching of the gospel can still be done by developing suitable models according to the needs of each person receiving Jesus Christ as Lord or Savior.
\end{abstract}

\begin{abstract}
Abstrak
Penginjilan mengalami banyak kendala, sehingga kurang bisa dilakukan dengan maksimal, berbagai tantangan yang dihadapi tidak dapat melemahkan semangat memenangkan jiwa bagi Yesus Kristus. Itulah sebabnya perlu upaya mengembangkan model penginjilan yang tepat. Penelitian ini menemukan 6 (enam) model penginjilan, yakni: interpersonal, pribadi, massal, pelayanan media, pelayanan sosial dan persahabatan. Metode penelitian yang digunakan kualitatif dengan pendekatan ilmu fenomenologi. Kesimpulannya, pekabaran Injil tetap dapat dilakukan dengan mengembangkan model yang cocok sesuai kebutuhan dengan tujuan setiap orang menerima Yesus Kristus sebagai Tuhan atau Juruselamat.
\end{abstract}

Article History

Submit:

16 April 2019

Revised:

11 Mei 2019

Accepted:

26 Oktober 2019

Keywords (kata kunci):

evangelism; types of

evangelism; today's mission; model penginjilan; misi masa kini

\section{Pendahuluan}

Tantangan yang dihadapi dalam penginjilan, semestinya tidak menciutkan para pekabar Injil, apalagi menghentikan aktivitas penginjilan. Kesulitan, hambatan atau apa pun alasannya semestinya mendorong para penginjil atau umat Allah untuk berserah pada Allah sembari mencari model-model yang cocok untuk eksis dalam penginjilan. Semangat untuk memenangkan jiwa bagi Yesus Kristus yang dikerjakan oleh Roh Kudus menjadi kekuatan untuk terus bersemangat dalam penginjilan.

Penginjilan adalah sebuah aktivitas untuk memberitakan Injil secara pribadi. Injil yang dimaksudkan adalah berita tentang Yesus Kristus yang mati, dikuburkan untuk menebus segala dosa manusia dan bangkit untuk memberikan hidup yang kekal, sebagaimana yang 
dijelaskan dalam surat I Korintus 15:3-4. Ada empat istilah yang pararel dalam bahasa Yunani yang digunakan untuk menyatakan tentang penginjilan: euangelizo artinya mengabarkan Injil atau kabar baik, kerusso artinya berkhotbah atau memproklamirkan, didasko artinya mengajar dan martureo artinya bersaksi. ${ }^{1}$ Oleh karena itu, penginjilan tidak hanya dipahami sebagai upaya untuk memberitakan Injil, namun juga berhotbah (dakwah), mengajar dan bersaksi yang tentunya mendukung perintah Amanat Agung Yesus Kristus untuk memuridkan (Mat. 28:19-20).

D. W. Ellis menjelaskan bahwa penginjilan merupakan upaya mewartakan: Yesus Kristus sebagai Juruselamat, sehingga setiap orang yang diinjili akan menerimaNya, taat dan melayaniNya, serta hidup dalam persekutuan gerejaNya. ${ }^{2}$ Hal yang senada juga dinyatakan oleh J. I. Packer bahwa penginjilan adalah pengkomunikasian yang dilakukan orang Kristen sebagai penyambung lidah Allah untuk menyampaikan berita pengampunan Allah kepada manusia berdosa. ${ }^{3}$

\section{Metode Penelitian}

Metode yang digunakan untuk peneliti ini adalah kualitatif karena penelitian dilakukan bersifat deskriptif dan cenderung menggunakan analisis. Penelitian kuantitatif berangkat dari teori menuju data, dan berakhir pada penerimaan atau penolakan terhadap teori. Jadi bertolak dari data, memanfaatkan teori yang ada sebagai bahan penjelas, dan berakhir dengan suatu "teori." Jenis penelitian kualitatif yang digunakan adalah fenomenologi artinya pelaksanaan penelitian didasarkan pada ciri-ciri intrinsik fenomen-fenomen yang dikerjakan oleh subyek (manusia).

Model penginjilan merupakan bentuk-bentuk atau model yang dilakukan oleh penginjil atau misionari Kristen dalam menyebarkan Injil keselamatan di dalam Yesus Kristus. Setidaknya ada 6 (enam) model penginjilan yang dapat dikembangkan di masa kini sebagai solusi atas kemandekan (terhambatan) pekabaran Injil. Pertama, model penginjilan interpersonal. Kedua, model penginjilan pribadi. Ketiga, model penginjilan massal. Keempat, model penginjilan pelayanan media. Kelima, model penginjilan pelayanan sosial. Keenam, model penginjilan persahabatan.

\section{Pembahasan}

Perhatian yang besar terhadap aktivitas penginjilan bukan hanya pada level jemaat, namun juga di kalangan mahasiswa teologi dan hamba-hamba Tuhan. Jamin Tanhidy pada tahun 2014 memberikan laporan hasil penelitian bahwa Sekolah Tinggi Teologi Simpson Ungaran Jawa Tengah melengkapi setiap mahasiswa program studi (prodi) S1 baik teologi maupun Pendidikan Agama Kristen (PAK) dengan mata kuliah Metode Penginjilan, yang disajikan kepada mahasiswa tingkat pertama, semester kedua. Namun ketika melakukan penginjilan mengalami kesulitan atau hambatan baik dari pihak mahasiswa sebagai penginjil maupun orang yang diinjili. Hal tersebut menjadi pendorong sehingga dilakukan evaluasi pada

\footnotetext{
${ }^{1}$ Yakob Tomatala, Penginjilan Masa Kini 2, cet. Pertama (Malang: Gandum Mas, 1998), 21-22.

${ }^{2}$ D. W. Ellis, Metode Penginjilan: Istimewa Tepat Guna Bagi Penginjil Awam Praktis dan Taktis (Jakarta: Yayasan Komunikasi Bina Kasih/OMF, 1999), 117.

${ }^{3}$ J. I. Packer, Penginjilan dan Kedaulatan Allah (Surabaya: Momentum, 2003), 29.
} 
semester genap tahun ajaran 2014-2015. Evaluasi dilakukan terhadap 13 orang dari prodi teologi dan 12 orang dari prodi PAK, dengan membagi praktik penginjilan menjadi lima kelompok.

Evaluasi dilakukan dengan menggunakan metode penelitian melalui:

FGD [Focus Group Discussion], wawancara terbuka, dan laporan praktik mahasiswa. Hasil penelitian yang diperoleh adalah: 1) Capaian praktik mahasiswa hanya sampai pada tahap penyampaian Injil: 2) Faktor kesulitan melaksanakan praktik PI [Pekabaran Injil] adalah faktor internal: $55,55 \%$, dan faktor eksternal: $44,44 \%{ }^{4}$

Hasil pencapaian praktek penginjilan sebagai berikut:

Tabel 1: Pencapaian Praktik Pekabaran Injil (PI) dalam Bentuk Prosentase ${ }^{5}$

\begin{tabular}{|l|c|c|c|c|}
\hline Tahapan & I & II & III & IV \\
\hline Perkenalan Injil & $60 \%$ & $40 \%$ & $32 \%$ & $32 \%$ \\
\hline A. Anugerah & $20 \%$ & $28 \%$ & $20 \%$ & $32 \%$ \\
\hline B. Allah & -- & $20 \%$ & $20 \%$ & $8 \%$ \\
\hline C. Kristus & $12 \%$ & $8 \%$ & $8 \%$ & $12 \%$ \\
\hline D. Iman & $8 \%$ & $4 \%$ & $12 \%$ & $16 \%$ \\
\hline
\end{tabular}

Jika memperhatikan tabel 1 di atas, maka diketahui bahwa mahasiswa dapat menyelesaikan pembicaraan tentang iman (terkait dengan Injil) pada: tahap I 8\%, tahap II 4\%, tahap III $12 \%$ dan tahap IV hanya 16\%. Artinya, mahasiswa melakukan penginjilan hanya pada tahap menyampaikan Injil (anugerah, Allah, Kristus dan iman), namun belum mencapai pada tahap menuntun orang yang diinjili menerima Yesus Kristus secara pribadi sebagai Tuhan atau Juruselamat, hal tersebut disebabkan adanya faktor internal dan eksternal sebagai penghalang. Tanhidy menjelaskan,

(1) Faktor internal: penyampaian masih kaku, rasa takut untuk masuk pada beberapa bagian pada tahap penyampaian Injil, rasa malas pada diri mahasiswa untuk dan melakukan praktik, kesulitan untuk menguasai metode sehingga lupa pada tahap atau bagian-bagian tertentu, mahasiswa merasa waktu yang dibutuhkan terlalu panjang sehingga orang yang dilayani kurang dapat memperhatikan dengan baik, dan kurangnya simulasi di kelas; (2) faktor eksternal adalah orang yang dilayani mengakhiri pembicaraan dan meninggalkan mahasiswa, metode yang digunakan terlalu panjang sehingga membuat orang yang dilayani merasa jenuh, orang yang dilayani merasa waktu mereka terlalu banyak tersita dalam pembicaraan, pembicaraan diganggu oleh orang lain. ${ }^{6}$

Hasil penelitian yang dilakukan oleh Tanhidy di atas menjadi alasan krusial untuk lebih serius memperhatikan kegiatan penginjilan agar efektif dan produktif, itulah sebabnya perlu kajian berbagai model penginjilan, sehingga ditemukan model yang cocok atau memenuhi kebutuhan. Bagian ini selanjutnya akan menjelaskan enam model penginjilan yang dapat

\footnotetext{
${ }^{4}$ Jamin Tanhidy, Praktik Metode Penginjilan Pada Mata Kuliah Metode Penginjilan STT Simpson Ungaran. Evangelikal: Jurnal Teologi Injili dan Pembinaan Warga Jemaat (online), Vol. 1, No. 1 (2017): Januari; 49. (https://journal.sttsimpson.ac.id/index.php/EJTI/article/view/55/39) Diakses tanggal 8 Mei 2019, jam 07:12pm

${ }^{5}$ Ibid., 51. Diakses tanggal 8 Mei 2019, jam 07:25pm

${ }^{6}$ Ibid., 53. Diakses tanggal 8 Mei 2019, jam 08:12pm
} 
dikembangkan di masa kini guna menjangkau (memenangkan) setiap jiwa sesat untuk menerima Yesus Kristus secara pribadi.

\section{Model Penginjilan Interpersonal}

Model penginjilan interpersonal ditunjukkan oleh Yesus Kristus terhadap Nikodemus. Model penginjilan ini sangat menarik untuk diperhatikan sebagaimana yang dijelaskan dalam Injil Yohanes 3:1-21. Ada tiga hal yang yang perlu diperhatikan terkait dengan model penginjilan interpersonal yang menekankan komunikasi yang bersifat interpersonal (antarpribadi): menghargai komunikasi interpersonal (ay. 1-2), memahami komunikasi interpersonal (ay. 3-6), menerapkan komunikasi interpersonal (ay. 7-21). Menghargai komunikasi interpersonal sebagaimana yang dinyatakan dalam Alkitab: ${ }^{1}$ adalah seorang Farisi yang bernama Nikodemus, seorang pemimpin agama Yahudi. ${ }^{2}$ Ia datang pada waktu malam kepada Yesus dan berkata: "Rabi, kami tahu, bahwa Engkau datang sebagai guru yang diutus Allah; sebab tidak ada seorang pun yang dapat mengadakan tanda-tanda yang Engkau adakan itu, jika Allah tidak menyertainya." 7

Sikap yang saling menghargai terlihat dari Yesus Kristus terhadap Nikodemus, demikian pula sebaliknya. Nikodemus adalah seorang Farisi dan seorang pemimpin agama Yahudi. Orang-orang Farisi sepanjang kesaksian Injil Yohanes umumnya bereaksi sinis terhadap pengajaran Yesus. Namun Nikodemus mempunyai tujuan yang sungguh-sungguh mencari Yesus, ia anggota Sanhedrin yang penting, hal ini menyebabkan Nikodemus enggan untuk mendekati Yesus secara terbuka. ${ }^{8}$ Nikodemus adalah seorang Farisi yang berusaha mengetahui siapa Yesus dengan benar walaupun diawal pemahamannya keliru tentang Yesus: "Yesus bukanlah Anak Allah." Ia tertarik oleh sifat dan pengajaran Yesus Kristus, tetapi karena takut diketahui oleh rekan sesama Farisi, maka ia datang kepada Yesus di malam hari. ${ }^{9}$ Istilah Nikodemus sebagai anggota Sanhedrin ${ }^{10}$ diterjemahkan dari bahasa Yunani a;rcwn tw/n VIoudai,wn (archōn tōn Ioudaiōn) ${ }^{11}$ dimaknai sebagai "a ruler of the Jewish (seorang raja, penguasa Yahudi)."

Dalam pemahaman Nikodemus, Yesus adalah seorang Rabi, guru yang diutus Allah. Istilah Rabi menjelaskan tentang panggilan kehormatan karena yang bersangkutan melakukan pekerjaan mengajar hukum-hukum Tuhan. Yesus dalam pemahaman Nikodemus melakukan hal tersebut sehingga patut disebut Rabi. ${ }^{12}$ Istilah "guru yang diutus Allah" merupakan sapaan Nikodemus terhadap Yesus, yang menunjukkan bahwa Yesus adalah pribadi yang melakukan tugas Ilahi, yang diperteguh dengan tanda-tanda Ilahi yang Yesus lakukan dalam pelayanan. ${ }^{13}$ Nikodemus berkomunikasi dengan Yesus memanfaatkan waktu yang tepat, yakni dimalam hari (ay. 2), hal ini dilakukan Nikodemus agar tidak diketahui orang lain demi

\footnotetext{
${ }^{7}$ Yohanes 3:1-2.

${ }^{8}$ Donald Guthrie, Tafsiran Alkitab Masa Kini, pen. W. B. Sijabat (Jakarta: Yayasan Komunikasi Bina Kasih/OMF, 1999), 3:285.

${ }^{9}$ R. E. Nixon, Ensiklopedi Alkitab Masa Kini (Jakarta: Yayasan Komunikasi Bina Kasih/OMF, 2000), 2:157.

${ }^{10}$ Hasan Sutanto, Perjanjian Baru Interlinear: Yunani-Indonesia dan Konkordansi Perjanjian Baru (Jakarta: Lembaga Alkitab Indonesia, 2004), 1:486.

${ }^{11}$ BibleWorks7, " a;rcwn tw/n VIoudai,wn," in Nicodemus Visits Jesus.

${ }^{12}$ F. Foulkes, Ensklopedi Alkitab Masa Kini (Jakarta: Yayasan Komunikasi Bina Kasih/OMF, 2000), 2:288. ${ }^{13}$ Guthrie, Tafsiran Alkitab Masa Kini, 3:284-85.
} 
mempertahankan (mengamankan) wibawa dirinya sebagai seorang Farisi dan pemimpin agama Yahudi. Pada ayat 2 terlihat jelas yang memulai komunikasi adalah Nikodemus. Nikodemus mengakui bahwa Yesus lebih berwibawa dari pada dirinya sendiri, atau sebagai seorang nabi, ${ }^{14}$ dan disertai Allah.

Model komunikasi interpersonal yang baik dapat dicermati dalam bagian ini yakni ketika: ${ }^{3}$ Yesus menjawab, kata-Nya: "Aku berkata kepadamu, sesungguhnya jika seorang tidak dilahirkan kembali, ia tidak dapat melihat Kerajaan Allah." ${ }^{4}$ Kata Nikodemus kepadaNya: "Bagaimanakah mungkin seorang dilahirkan, kalau ia sudah tua? Dapatkah ia masuk kembali ke dalam rahim ibunya dan dilahirkan lagi?" ${ }^{5}$ Jawab Yesus: "Aku berkata kepadamu, sesungguhnya jika seorang tidak dilahirkan dari air dan Roh, ia tidak dapat masuk ke dalam Kerajaan Allah. ${ }^{6}$ Apa yang dilahirkan dari daging, adalah daging, dan apa yang dilahirkan dari Roh, adalah roh. ${ }^{15}$ Penginjilan pribadi dari Yesus Kristus terhadap Nikodemus yang begitu komunikatif secara interpersonal ditandai dengan percakapan yang begitu jelas atau terperinci, dimana Yesus Kristus menyatakan bahwa kelahiran kembali merupakan proses untuk melihat kerajaan Allah (ay. 3) dan bersifat rohani sehingga dapat melihat kerajaan Allah (ay. 4-6).

Makna kalimat "jika seorang tidak dilahirkan kembali, ia tidak dapat melihat Kerajaan Allah (ay. 3)," menekankan pentingnya kelahiran baru sebagai syarat mutlak untuk menerima atau memperoleh hidup yang kekal melalui Yesus Kristus. Chris Marantika menjelaskan istilah kelahiran baru berasal dari bahasa Yunani genethe anothen berarti "kembali" dan juga "dari atas" (Yoh. 3:3; 19:11). ${ }^{16}$ Selanjutnya Guthrie menjelaskan istilah lahir baru identik dengan dilahirkan kembali atau dilahirkan dari atas, ${ }^{17}$ secara teologis dapat diartikan sebagai aktivitas Roh Allah yang memberikan kodrat baru kepada seseorang berdosa didasari oleh karena ia telah menerima Yesus Kristus sebagai Tuhan dan Juru Selamat secara pribadi. ${ }^{18}$ Kelahiran baru bukanlah sekedar emosi melainkan pengalaman iman yang menjadikan seseorang memiliki kodrat baru yaitu kodrat Allah, hal ini merupakan pekerjaan Roh Allah yang terjadi ketika seseorang menerima Yesus. ${ }^{19}$ Kelahiran baru merupakan kegiatan Allah yang terjadi hanya bagi orang percaya dan hal tersebut merupakan anugerah karena seseorang mengalami pengampunan dosa dengan menerima Yesus secara pribadi. Setiap orang yang sudah lahir baru selayaknya berkomitmen untuk hidup tidak di dalam dosa lagi, melainkan hidup dipimpin oleh Roh Allah sehingga menampilkan hidup yang sesuai kehendak Allah yakni menjadi garam dan terang dunia. ${ }^{20}$

Chris Marantika menjelaskan kelahiran baru membuktikan bahwa setiap orang percaya tetap sama dalam kepribadian, berbeda dalam gaya hidup (dikendalikan Roh Kudus), ${ }^{21}$ namun

\footnotetext{
${ }^{14}$ Dave Hagelberg, Tafsiran Injil Yohanes (Pasal 1-5) Dari Bahasa Yunani (Yogyakarta: Yayasan ANDI, 1999), 115.

${ }^{15}$ Yohanes 3:3-6.

${ }^{16}$ Chris Marantika, Doktrin Keselamatan dan Kehidupan Rohani (Yogyakarta: Iman Press, 2004), 100.

${ }^{17}$ Guthrie, Tafsiran Alkitab Masa Kini, 3:285.

${ }^{18}$ Marantika, Doktrin Keselamatan dan Kehidupan Rohani, 101.

${ }^{19}$ Ibid., 103.

${ }^{20}$ Donald C. Stamps, ed. um., "Yohanes," dalam Alkitab Penuntun Hidup Berkelimpahan, pent. Nugroho Hananiel, peny. Bertha Gaspersz (Malang: Gandum Mas, 1984), 1705.

${ }^{21}$ Marantika, Doktrin Keselamatan dan Kehidupan Rohani, 106-107.
} 
ini juga tidak menunjukkan bahwa orang tersebut menjadi sempurna secara rohani. Sementara itu, M. R. Gordon menjelaskan kelahiran baru merupakan aktivitas Roh Allah, yang harus diresponi dengan berkomitmen melakukan atau hidup sesuai kehendak Allah. ${ }^{22}$ Donald Guthrie menjelaskan bahwa hanya orang yang melangkah dengan iman yang dapat memasuki atau 'melihat' kerajaan. 'Melihat' dalam arti ini dapat dipahami sebagai mengalami (bnd. ay. 36). Kelahiran baru mendahului dan bukan mengikuti perbuatan 'melihat. ${ }^{, 2}$

Komunikasi Yesus yang menyatakan "Aku berkata kepadamu, sesungguhnya jika seorang tidak diperanakkan kembali, ia tidak dapat melihat Kerajaan Allah" meluruskan seluruh pemahaman dasar keagamaan dan pengertian mengenai "Kerajaan Allah" yang dimiliki Nikodemus. ${ }^{24}$ Nikodemus yang begitu setia dalam menjalankan ajaran agama Yahudi berpikir pasti masuk "Kerajaan Allah.," 25 Nikodemus yang adalah pemimpin agama Yahudi, seorang Farisi yang beradab, beramal dan taat secara agamawi ternyata "tidak dapat melihat Kerajaan Allah." Yesus mendorong Nikodemus agar tidak bersandar pada perbuatan baik dan jabatan (pemimpin agama Yahudi) sebab Nikodemus pun butuh Juru Selamat. Dalam posisi semacam ini, seseorang tidak mungkin melihat kerajaan Allah jika tidak terlebih dahulu mengalami kelahiran kembali atau kelahiran dari atas yaitu menerima Yesus secara pribadi. Istilah "Kerajaan Allah" menunjuk kepada kehidupan kekal yang hanya diperoleh (dialami) oleh orang percaya. ${ }^{26}$ Proses kelahiran baru merupakan proses untuk melihat kerajaan Allah (hidup kekal), hal ini bukanlah sekedar emosi melainkan pengalaman iman yang dikerjakan Allah. Hal ini disebutkan dalam beberapa ayat dalam Alkitab di Yohanes pasal 3 (tiga).

Ayat 4 menyatakan Kata Nikodemus kepada-Nya: "Bagaimanakah mungkin seorang dilahirkan, kalau ia sudah tua? Dapatkah ia masuk kembali ke dalam rahim ibunya dan dilahirkan lagi?" Ayat tersebut menunjukkan bahwa Nikodemus tampaknya bingung, kaget karena Guru yang sangat dihargainya berkata bahwa ia harus "dilahirkan lagi." Istilah "Dapatkah ia masuk kembali ke dalam rahim ibunya dan dilahirkan lagi?" menjelaskan bahwa Nikodemus berpikir adalah mustahil untuk memulai sesuatu yang baru yaitu "kelahiran kembali" baginya sebagai seorang Farisi ataupun pemimpin agama Yahudi. ${ }^{27}$ Pada ayat 5 dinyatakan Yesus menjawab: "Aku berkata kepadamu, sesungguhnya jika seorang tidak dilahirkan dari air dan Roh, ia tidak dapat masuk ke dalam Kerajaan Allah. Guthrie selanjutnya menjelaskan ada dua pandangan sehubungan dengan "dilahirkan dari air," pertama berhubungan dengan baptisan; kedua, kelahiran alamiah. ${ }^{28}$

Memahami istilah "dilahirkan dari air" tidaklah perlu memperdebatkan kedua makna tersebut, sebab yang terpenting tekanan istilah "dilahirkan dari air" bukan pada "air" melainkan pada "Roh" sebagaimana yang dinyatakan dalam ayat 6-8. Donald C. Stamps

\footnotetext{
${ }^{22}$ M. R. Gordon, "Lahir, Lahir Kembali,” dalam Ensiklopedi Alkitab Masa Kini, pent. Broto Semedi (Jakarta: Yayasan Komunikasi Bina Kasih/OMF, 2000), 1:627.

${ }^{23}$ Guthrie, Tafsiran Alkitab Masa Kini, 3:285.

${ }^{24}$ Leon Morris, "The Gospel According to Jhon," dalam The New International Commentary on the New Testament (Grand Rapids: William B. Eerdmans Publishing Company, 1971), 212.

${ }^{25}$ D. A. Carson, The Gospel According to Jhon (England: Inter-Varsity Press and Grand Rapids: William B. Eerdmans Publishing, 1991), 189.

${ }^{26}$ Hagelberg, Tafsiran Injil Yohanes (Pasal 1-5) Dari Bahasa Yunani, 117.

${ }^{27}$ Guthrie, Tafsiran Alkitab Masa Kini, 3:285.

${ }^{28}$ Ibid., 3:285.
} 
menjelaskan bahwa Yesus mungkin sekali sedang menunjuk kepada karya penyucian oleh Roh Kudus dalam kelahiran baru. Dalam Titus 3:5 Paulus berbicara tentang "permandian kelahiran kembali dan pembaharuan yang dikerjakan oleh Roh Kudus."29

Untuk memahami ayat 5 sebaiknya juga memperhatikan ayat 6, yang menyatakan: Apa yang dilahirkan dari daging, adalah daging, dan apa yang dilahirkan dari Roh, adalah roh. Pengertian ayat 6 mempertegas bahwa sumber yang melahirkan menjadi penentu dari yang dilahirkan. Bila yang melahirkan "daging," maka yang dilahirkan "daging." Bila yang melahirkan "Roh," maka yang dilahirkan juga "roh." Guthrie menjelaskan bahwa Tuhan Yesus menunjukkan bahwa tabiat dari mereka yang melahirkan ditentukan oleh sumber yang melahirkan mereka. ${ }^{30}$ Yesus mengkomunikasikan kepada Nikodemus bahwa setiap orang harus "diperanakkan" dari manusia dan juga dari Roh Allah. Bila seseorang mau terlibat dalam "Kerajaan Allah," orang tersebut harus diciptakan ulang sebagai ciptaan rohani, yakni dilahirkan dari air dapat diartikan sebagai kelahiran fisik, sedangkan dilahirkan dari Roh menjelaskan kelahiran rohani di dalam Yesus, hal ini dipahami kemudian oleh komunikan, dalam konteks ini adalah Nikodemus.

Komunikator yang bersifat interpersonal menerapkan tihal penting: (a) Accuracy Communication (ay. 7-8), (b) Brevity Communication (ay. 9-12) dan (c) Clarity Communication (ay. 13-21). Accuracy Communication (berkomunikasi dengan akurat) dijelaskan begitu nyata dalam ayat 7-8. Pada ayat 7 ditulis: Janganlah engkau heran, karena Aku berkata kepadamu: Kamu harus dilahirkan kembali. Istilah "Kamu harus dilahirkan kembali" mempertegas bahwa kelahiran baru bukan hanya kebutuhan tetapi keharusan. Kelahiran kembali bukan untuk dipilih tetapi wajib untuk dialami. ${ }^{31}$ Yesus Kristus berkomunikasi secara akurat dengan Nikodemus yang adalah seorang pemimpin Yahudi, dan mewakili umat Israel. Nikodemus sebagai pemimpin yang terpelajar yang membaca kitab Perjanjian Lama semestinya mengerti bahwa manusia "harus diperanakkan kembali."

Pada ayat 8 dituliskan "Angin bertiup ke mana ia mau” dalam pandangan Guthrie, angin menggambarkan kegiatan-kegiatan Roh. Mujizat kelahiran baru tak dapat diukur oleh kecerdikan manusia. ${ }^{32}$ Hal senada juga diungkapkan Stamps "Sebagaimana halnya dengan angin, sekalipun tidak tampak, namun diketahui karena aktivitas dan desirannya, demikian pula Roh Kudus diketahui melalui kegiatan dan efeknya atas mereka yang dilahirkan kembali."33 Secara akurat Yesus mengkomunikasikan kepada Nikodemus bahwa “diperanakkan dari Roh" adalah sesuatu yang sulit untuk dipahami dan merupakan misteri Ilahi, namun hal tersebut tidak berarti membebaskan Nikodemus dari teguran tersebut. Sekalipun Nikodemus merupakan seorang Farisi dan pemimpin agama Yahudi, ia tetap harus "diperanakkan dari Roh."

Brevity Communication (komunikasi yang ringkas) dapat dilihat pada ay. 9-12). Pada ayat 9 dinyatakan Nikodemus menjawab, katanya: "Bagaimanakah mungkin hal itu terjadi?" Jawaban Nikodemus begitu ringkas yang menunjukkan bahwa Nikodemus tidak percaya atau

\footnotetext{
${ }^{29}$ Stamps, ed. um., "Yohanes," dalam Alkitab Penuntun Hidup Berkelimpahan, 1701.

${ }^{30}$ Guthrie, Tafsiran Alkitab Masa Kini, 3:286.

${ }^{31}$ Ibid., 3:286.

${ }^{32}$ Ibid., 3:286.

${ }^{33}$ Stamps, Alkitab Penuntun Hidup Berkelimpahan, 1704.
} 
menerima Yesus, ${ }^{34}$ sekalipun dalam ayat 2 Yesus disebut Rabi, kami tahu, bahwa Engkau datang sebagai guru yang diutus Allah. Pada ayat 10 Yesus menjawab: "Engkau adalah pengajar Israel, dan engkau tidak mengerti hal-hal itu? Yesus juga menjawab Nikodemus dengan ringkas, menyebut Nikodemus "pengajar Israel."

Nikodemus sebagai "pengajar Israel" merupakan perwakilan pengajar Israel lainnya semestinya mengerti perihal proses terjadi kelahiran kembali tetapi gagal. ${ }^{35}$ Nikodemus sebagai guru Israel, yang sudah mempelajari Firman Tuhan, dia seharusnya mengerti bahwa status dan usaha tidak dapat membawa manusia ke dalam Kerajaan Allah. ${ }^{36}$ Pada ayat 11 dinyatakan "kami berkata-kata tentang apa yang kami ketahui" mempertegas bahwa pengajaran Yesus ataupun murid-murid-Nya berbeda, bahkan sangat berwibawa dibanding para Rabi. ${ }^{37}$

Nikodemus datang kepada Yesus disebabkan "tanda-tanda" bukan karena mau "menerima kesaksian Yesus." rela untuk menerima Yesus, sekalipun ia pengajar Israel yang semestinya membuka hati untuk hal tersebut. Nikodemus tertarik kepada Yesus karena tanda-tanda yang dibuat Yesus tetapi tidak berniat menerima Yesus secara pribadi. Pada ayat 12 ditulis: Kamu tidak percaya, waktu Aku berkata-kata dengan kamu tentang hal-hal duniawi, bagaimana kamu akan percaya, kalau Aku berkata-kata dengan kamu tentang hal-hal sorgawi? 'Hal-hal duniawi' haruslah dihubungkan dengan pernyataan yang terdahulu, yang meliputi kebenaran-kebenaran rohani, seperti kelahiran baru. 'Hal-hal sorgawi' adalah kebenaran-kebenaran yang tak dapat sepenuhnya dinyatakan di dunia ini. ${ }^{39}$ Jadi, Nikodemus pada dasarnya tidak siap "percaya Yesus" sekalipun Yesus memberikan argumentasi yang meliputi hal-hal duniawi dan hal-hal sorgawi.

Clarity Communication (komunikasi yang jelas). Ayat 13 menyatakan "Tidak ada seorangpun yang telah naik ke sorga, selain dari pada Dia yang telah turun dari sorga, yaitu Anak Manusia." Pribadi yang telah naik ke sorga dan telah turun dari sorga menegaskan bahwa yang dimaksudkan tidak ada yang lain kecuali Yesus Kristus dan sekaligus mempertegas pentingnya diperanakkan dari atas. Dave Hagelberg memberi komentar "Dia yang telah turun dari surga" untuk menguraikan mengenai hal-hal surgawi dan juga merupakan cara supaya manusia dapat diperanakkan dari atas. ${ }^{40}$

Istilah "ditinggikan" dalam ayat 14 menekankan satu kesamaan antara "ular" itu dan Tuhan Yesus, yaitu bahwa dua-duanya "harus ditinggikan", tetapi sebenarnya kesamaannya lebih luas, karena tampaknya "ular" itu melambangkan dosa umat Israel, dan waktu Dia disalibkan Tuhan Yesus menjadi dosa untuk kita. ${ }^{41}$ Ayat 15 merupakan kelanjutan ayat 14 yang menyatakan: supaya setiap orang yang percaya kepada-Nya beroleh hidup yang kekal.

\footnotetext{
${ }^{34}$ Hagelberg, Tafsiran Injil Yohanes (Pasal 1-5) Dari Bahasa Yunani, 122.

${ }^{35}$ Guthrie, Tafsiran Alkitab Masa Kini, 3:286.

${ }^{36}$ Hagelberg, Tafsiran Injil Yohanes (Pasal 1-5) Dari Bahasa Yunani, 123.

${ }^{37}$ Guthrie, Tafsiran Alkitab Masa Kini, 3:286.

${ }^{38}$ Hagelberg, Tafsiran Injil Yohanes (Pasal 1-5) Dari Bahasa, 123-124.

${ }^{39}$ Guthrie, Tafsiran Alkitab Masa Kini, 3:286.

${ }^{40}$ Hagelberg, Tafsiran Injil Yohanes (Pasal 1-5) Dari Bahasa Yunani, 125.

${ }^{41}$ Ibid., 125.
} 
Kata sifat "kekal" mengungkapkan ketidak-dapat dihancurkannya hidup yang diterima itu. ${ }^{42}$ Hidup yang kekal diperoleh oleh setiap orang percaya, sehingga Nikodemus pun harus percaya kepada Yesus Kristus.

Istilah "karena" dalam ayat 16 agaknya menekankan hubungan dengan pembicaraan terdahulu dan mendukung pendapat bahwa Yesuslah yang berbicara. ${ }^{43}$ Menurut Guthrie, komunikasi Yesus terhadap Nikodemus begitu jelas, khususnya pada ayat 16. Pernyataan bahwa "begitu besar kasih Allah akan dunia ini" menunjukkan bahwa sasaran kasih Allah adalah universal meliputi segenap umat manusia. ${ }^{44}$ Jadi, Yesus mengkomunikasikan begitu jelas, "yang naik dan turun ke sorga" adalah Anak Manusia atau Yesus Kristus, Anak Tunggal Bapa yang dikaruniakan untuk manusia yang didasarkan pada kasih Allah yang begitu besar supaya setiap orang yang percaya kepada-Nya tidak binasa melainkan beroleh hidup yang kekal. Pada ayat 17 ditulis: Sebab Allah mengutus Anak-Nya ke dalam dunia bukan untuk menghakimi dunia, melainkan untuk menyelamatkannya oleh Dia. Ayat 17 begitu jelas menyatakan bahwa tujuan Allah mengutus misi Anak-Nya bukanlah untuk menghukum melainkan untuk menyelamatkan. ${ }^{45}$

Pada ayat 18 menjelaskan "Barangsiapa percaya kepada-Nya, ia tidak akan dihukum; barangsiapa tidak percaya, ia telah berada di bawah hukuman, sebab ia tidak percaya dalam nama Anak Tunggal Allah," menekankan bahwa syarat keselamatan yaitu barangsiapa yang percaya; alamat atau sasaran kepercayaan adalah Anak Tunggal Allah yang sekaligus merupakan tujuan Injil. Yesus mengkomunikasikan begitu jelas kepada Nikodemus bahwa setiap orang yang percaya kepada-Nya tidak dihukum, sebaliknya setiap orang yang menolakNya berada di bawah hukuman. Keselamatan hanya dapat diperoleh oleh mereka yang percaya. Dinyatakan secara khas ialah oleh nama Anak Tunggal Allah. ${ }^{46}$

Pernyataan "dan inilah hukuman itu: Terang telah datang ke dalam dunia, tetapi manusia lebih menyukai kegelapan dari pada terang, sebab perbuatan-perbuatan mereka jahat" pada ayat 19 disoroti oleh Stamps bahwa salah satu dari ciri dasar orang fasik adalah bahwa mereka mengasihi kegelapan, yaitu mereka menikmati dosa dan imoralitas (Rm. 1:18-32; Fil. 3:19; 2Tim. 3:2-5; 2Pet. 2:12-15). ${ }^{47}$ Jadi, Yesus begitu jelas mengkomunikasikan bahwa Ia datang bukan untuk menghakimi dunia tetapi karena ketidak percayaan seseorang, maka orang tersebut berada di bawah hukuman. "Terang” yang adalah Yesus Kristus, yang ditolak karena "lebih menyukai kegelapan" mengakibatkan tidak memperoleh keselamatan.

Sementara pada ayat 20 ditulis sebab barangsiapa berbuat jahat, membenci terang dan tidak datang kepada terang itu, supaya perbuatan-perbuatannya yang jahat itu tidak nampak. Kasih manusia akan kegelapan bukanlah demi kepentingannya sendiri, tapi karena kegelapan dapat menyembunyikannya. Sebaliknya, perbuatan-perbuatan yang benar menyambut terang karena terang dapat menyatakannya. ${ }^{48}$ Yesus Kristus melakukan komunikasi begitu jelas

\footnotetext{
${ }^{42}$ Guthrie, Tafsiran Alkitab Masa Kini, 3:287.

${ }^{43}$ Ibid., 3:287.

${ }^{44}$ Ibid., $3: 287$.

${ }^{45}$ Ibid., 3:287.

${ }^{46}$ Ibid., 3:287.

${ }^{47}$ Stamps, ed. um., "Yohanes," dalam Alkitab Penuntun Hidup Berkelimpahan, 1704.

${ }^{48}$ Guthrie, Tafsiran Alkitab Masa Kini, 3:287.
} 
bahwa orang yang melakukan kebenaran tidak menjauhi terang, melainkan datang kepada terang, hal tersebut terjadi karena kuasa dan kehendak Allah serta merupakan kemegahan di dalam Allah.

\section{Model Penginjilan Pribadi}

Menurut Brother William model penginjilan pribadi merupakan model penginjilan akhir zaman yang efektif. ${ }^{49}$ Setidaknya ada empat materi yang dapat digunakan untuk penginjilan pribadi, yakni: empat hukum rohani, empat fakta rohani, AMAKI, dan buku tanpa kata. Empat hukum rohani yang dimaksudkan adalah: pertama, Tuhan Allah mengasihi saudara, dan mempunyai suatu rencana yang indah bagi hidup saudara. Kedua, manusia penuh dosa dan terpisah dari Tuhan Allah, sehingga ia tidak dapat mengetahui dan mengalami kasih serta rencana Allah bagi hidupnya. Ketiga, Yesus Kristus adalah satu-satunya jalan keselamatan yang telah ditentukan oleh Tuhan Allah untuk keampunan dosa manusia, melalui Dia saudara dapat mengetahui dan mengalami kasih dan rencana Allah bagi saudara. Keempat, kita harus menerima Yesus Kristus menjadi Juruselamat dan Tuhan kita, dengan mengundang-Nya secara pribadi, dengan demikian kita dapat mengetahui dan mengalami kasih dan rencana Allah bagi hidup kita. ${ }^{50}$

Empat fakta rohani yang dimaksudkan adalah: pertama, dosa dan hukumannya. Kedua, usaha manusia sia-sia adanya. Ketiga, Yesuslah jalan, dan keempat, menerima Yesus. ${ }^{51}$ AMAKI merupakan kepanjangan dari Anugerah, Manusia, Allah, Kristus, Iman. ${ }^{52}$ Buku tanpa kata yang dimaksudkan adalah kertas yang berwarna tanpa kata sendikitpun. Warna tersebut meliputi: emas, hitam, merah, putih dan hijau. ${ }^{53}$ Dengan demikian, model penginjilan pribadi dapat dilakukan secara personal (one to one), dimana komunikator dapat memilih salah satu

\footnotetext{
${ }^{49}$ Brother William, Penginjilan Akhir Zaman, pent. Yeri Ekomunajat, peny. Eva Yunita (Yogyakarta: ANDI Offset, 2007), 145.

${ }^{50}$ Lihat Lembaga Pelayanan Mahasiswa Indonesia, Empat Hukum Rohani (Jakarta: Lembaga Pelayanan Mahasiswa Indonesia, t. t.), 2-8.

${ }^{51}$ Lihat Stanley Heath, Penginjilan dan Pelayanan Pribadi (Surabaya: YAKIN, 1979), 34-40. Heath menjelaskan argumentasi dengan membangun konsep yang dibangun dari Alkitab: Fakta pertama (dosa dan hukumannya), menekankan bahwa "saya telah berbuat dosa dan patut menerima maut yang kekal (Rm. 3:23; 6:23; Yes. 59:2). Fakta kedua (usaha manusia sia-sia adanya), menekankan bahwa "saya tidak sanggup melepaskan diri saya dari hukuman maut itu (Ef. 2:8-9; Rm. 3:20; Yoh. 14:6). Fakta ketiga (Yesuslah jalan), menekankan bahwa "Yesus adalah jalan satu-satunya bagi pelepasan saya karena Ia telah menjadi pengganti saya untuk dihukum pada kayu salib itu (Rm. 5:8; 1Pet. 2:24; 3:18). Fakta keempat (menerima Yesus), menekankan bahwa "Untuk memperoleh keselamatan yang telah Yesus sediakan, saya harus menerima Dia secara pribadi (Yoh. 1:12; Why. 3:20).

${ }^{52}$ Lihat D. James Kennedy, Ledakan Penginjilan (Jakarta: IFTJ Jaffray Jakarta, t. t.), 57-58. Kennedy menuliskan: Anugerah surga adalah pemberian cuma-cuma dan tidak dapat dibeli atau tidak pantas kita peroleh. Manusia berdosa dan tidak dapat menyelamatkan diri sendiri. Allah adalah penuh rahmat (karena itu tidak ingin menghukum kita) dan adil (karena itu harus menghukum dosa). Hakekat Kristus adalah Allah Insan yang kekal, mati disalib dan bangkit dari maut untuk menebus dosa-dosa dan menyediakan tempat di surga yang diberikan dengan cuma-cuma. Adapun Iman adalah bukan sekedar persetujuan menurut akal atau kepercayaan melainkan juga percaya Yesus Kristus saja yang memberikan keselamatan kekal.

${ }^{53}$ Menurut Sam Doherty bahwa warna emas menggambarkan tentang Allah, kekudusanNya dan Sorga. Warna hitam menggambarkan tentang dosa dan akibat-akibatnya. Warna merah menggambarkan tentang Yesus Kristus dan kematian-Nya untuk dosa. Warna putih menggambarkan tentang keselamatan, khususnya tentang pembenaran. Warna hijau menggambarkan tentang pertumbuhan rohani, sesudah diselamatkan. Lihat, Sam Doherty, Mengapa Menginjili Anak-anak? (Jakarta: Lembaga Penginjilan Anak-anak Indonesia, t. t.), 94.
} 
materi dari: empat hukum rohani, empat fakta rohani, AMAKI, dan buku tanpa kata, yang selanjutnya disampaikan kepada komunikan.

\section{Model Penginjilan Massal}

Model penginjilan massal dapat ditunjukkan dengan cara komunikator menyampaikan pesan Injil kepada masyarakat secara massal (ramai). Hal ini dapat dilakukan dalam bentuk Kebaktian Kebangunan Rohani (KKR). Melalui KKR firman Allah diberitakan, biasanya disertai dengan berbagai mujizat, seperti: kesembuhan fisik (physical healing), penyembuhan batin (inner healing), pelepasan dari keterikatan roh-roh jahat (okultisme) dan tantangan untuk menerima Yesus Kristus secara pribadi sebagai Juru Selamat. Brother William memperkuat dengan menyatakan bahwa selama KKR, mujizat-mujizat besar terjadi. Banyak orang yang belum percaya datang ke KKR dan menerima Kristus. ${ }^{54}$ Penginjilan massal akan produktif bila didahului dengan persiapan yang memadai oleh panitia. Panitia menjadi penggerak yang tentunya harus mendapatkan perkenanan Tuhan dan dukungan jemaat. Panitia membuat tim doa dan puasa, tim penggalangan dana untuk kepentingan KKR, ijin keramaian dan hal terkait lainnya, maka hasilnya akan terlihat, yakni petobat baru yang menerima Yesus Kristus secara pribadi atau pembaharuan komintmen spiritual bagi yang membutuhkan.

\section{Model Penginjilan Pelayanan Media}

Model penginjilan pelayanan media dapat dilakukan dengan menggunakan media baik media cetak maupun media elektronik. Media cetak dapat berupa koran, buletin, majalah, buku, jurnal yang berisikan tentang pengetahuan bahwa Yesus Kristus adalah Juru Selamat yang memberikan pengampunan dosa dan menjamin untuk memperoleh hidup yang kekal. Teks-teks yang bisa digunakan untuk diuraikan melalui media sebagai sarana penginjilan adalah Yesaya 59:2; Roma 3:23; Ibrani 9:27; Wahyu 21:8; Efesus 2:8-9; Yohanes 5:24; Kisah Rasul 4:12; I Korintus 15:3-4; I Petrus 3:18; Yohanes 3:16; 14:6; 1:12; Wahyu 3:20; I Yohanes 5:11-13. ${ }^{55}$ Sementara George W. Peters memperkenalkan model penginjilan melalui buku atau kitab Kisah Para Rasul sebagai berikut: pemberitaan Injil di depan umum, penginjilan kelompok kecil, penginjilan ke rumah-rumah, penginjilan kepada komunitas (kelompok masyarakat), penginjilan daerah atau kawasan (regional), penginjilan pribadi, penginjilan informal. ${ }^{56}$ Steaven Octavianus sebagai penggiat penginjilan pelayan media memberikan laporan penelitian:

... penggunaan aplikasi "yesHeis" dalam membagikan video di media sosial Facebook serta tanggapan dari orang Kristen mengenai aplikasi tersebut. Penelitian ini menggunakan pendekatan kualitatif dengan metode analisis deskriptif. Berdasarkan penelitian ini banyak masyarakat yang memberikan respon positif atas aplikasi ini.

\footnotetext{
${ }^{54}$ William, Penginjilan Akhir Zaman, 141.

${ }^{55}$ Johny Christofel Kalalo, Penginjilan "Mengasihi" Sistim Sokratik (Yogyakarta: Sekolah Tinggi Theologia Injili Indonesia, 2000), 23-24.

${ }^{56}$ George W. Peters, Teologi Pertumbuhan Gereja, pent. Gandum Mas, cet. Pertama (Malang: Gandum Mas, 2002), 226

${ }^{56}$ Steaven Octavianus, Analisis Penggunaan Aplikasi “yesHeis” Dalam Penginjilan Pribadi. Evangelikal: Jurnal Teologi Injili dan Pembinaan Warga Jemaat (online), Vol. 2, No. 1 (2018): Januari; 68. (https://journal.sttsimpson.ac.id/index.php/EJTI/issue/view/11) Diakses tanggal 9 Mei 2019, jam 08:26am.
} 
Namun walaupun banyak orang secara positif merespon aplikasi ini mereka masih ragu untuk membagikan bahkan menginstalnya di telepon pintarnya. ${ }^{57}$

Octavianus melakukan penginjilan dengan metode yang modern yakni menggunakan teknologi aplikasi yesHeis. Aplikasi ini sangat mudah diakses (http://id.yesheis.com/id/), suatu usaha penginjilan yang bertujuan untuk memberitakan keselamatan di dalam Yesus Kristus dengan jangkauan yang sangat luas tanpa dibatasi oleh ruang, waktu dan gerak. Hal ini dilakukan Octavianus karena adanya motivasi yang kuat untuk memenangkan jiwa-jiwa bagi Yesus Kristus. Penginjilan merupakan suatu kewajiban yang harus dipenuhi dan menjadi gaya hidup yang seyogyanya dipertahankan. Penginjilan yesHeis diterapkan oleh Octavianus meneruskan model penginjilan yang sebelumnya telah dilakukan oleh Pasasa yang juga menggunakan internet sebagai media teknologi yang sangat diminati di era ini. Octavianus memberikan komentar "Dalam penelitiannya Pasasa menyatakan bahwa kemajuan teknologi dan media internet menyediakan begitu banyak peluang untuk mewartakan Injil."58 Aplikasi yesHeis mendapatkan respons positif dan negatif sebagaimana yang disimpulkan oleh Octavianus:

Berdasarkan hasil wawancara dan observasi atas komentar dan respons mengenai aplikasi ini tanggapan positif lebih banyak diberikan daripada tanggapan yang negatif. Namun begitu walaupun banyak yang memberikan respons positif tidak banyak orang yang mau membagikan video ataupun isi dari aplikasi maupun halaman Facebook nya. Hal ini menjadi sebuah bias ketika ada orang yang secara positif merespon aplikasinya namun masih ragu untuk membagikan bahkan menginstalnya di telepon pintarnya. Beberapa respons negatif atas aplikasi ini adalah karena beberapa orang tidak mendapati aplikasi ini menarik atau sesuai dengan kebutuhan mereka. ${ }^{59}$

Setelah memperhatikan laporan Octavianus di atas, maka sebaiknya aplikasi yesHeis tetap digunakan dengan melakukan berbagai perbaikan pada video secara profesional terkait gambar-gambar, isi tulisan dan sebaiknya disertai suara musik atau sejenisnya agar lebih menarik. Penginjilan menggunakan media dapat dilakukan dengan menggunakan tulisan, Short Message Service (SMS), website, cetakan, line, whatApp, email, telepon, facebook, messenger, twitter, dan lain-lain. Masyarakat kota di Indonesia dapat dijangkau dengan media melalui berbagai macam media-surat kabar, majalah, radio, televisi, film, drama dan lainlain. ${ }^{60}$ Media cetak dan elektronik harus dikelola dengan manajemen yang baik, sehingga baik isi maupun packaging design dapat menarik perhatian untuk dibaca, didengarkan dan diperhatikan oleh umat.

Penginjilan yang disampaikan melalui media cetak dan media elektronik, sangat diharapkan dapat diakses dengan cepat. Komunikator harus penginjilan menjadi menarik, komunikatif, dapat divisualisasikan dan mudah direkam oleh otak pembaca atau pendengar, dengan demikian akan ada orang-orang yang terbuka hatinya untuk menerima Yesus Kristus secara pribadi Tuhan atau Juruselamat.

\footnotetext{
${ }^{57}$ Ibid., 70. Diakses tanggal 9 Mei 2019, jam 08:35am.

${ }^{58}$ Ibid., 73. Diakses tanggal 9 Mei 2019, jam 08:43am.

${ }^{58}$ Ed Travis, Kepemimpinan Gereja Masa Kini (Tangerang: Yayasan Damai Mulia, 2005), 170.
} 


\section{Model Penginjilan Pelayan Sosial}

Model penginjilan pelayanan sosial dapat dilakukan, melalui: kunjungan ke rumah sakit, pendidikan, pemberian bantuan bencana alam dan sejenisnya. Pelayanan tersebut bukan merupakan tindakan Kristenisasi melainkan membangun "jembatan" komunikasi untuk menyatakan ajaran Yesus Kristus yang sangat khas yakni kasih. Kasih harus diimplementasikan terhadap semua orang sebagai kesaksian bahwa umat Kristiani melakukan yang Yesus Kristus ajarkan. World Harvest Center (Yayasan Tuaian Dunia) yang berada di Tangerang telah memulai pelayanan sosial melalui Harvest Community Development dan Harvest Peduli. Harvest Community Development adalah departemen yang khusus menangani masyarakat yang membutuhkan bantuan modal dan pemberian bea siswa, dan kesehatan. Harvest Peduli adalah "kendaraan" yang digunakan untuk memberikan bantuan bencana alam baik di Indonesia maupun di luar negeri. ${ }^{61}$ Melalui pelayanan sosial tersebut terbuka jembatan untuk melakukan penginjilan tentu harus dilakukan dengan penuh hikmat dan iman kepda Yesus Kristus.

\section{Model Penginjilan Persabatan}

Harming melaporkan pendekatan penginjilan yang Yesus Kristus lakukan, khususnya terhadap perempuan Samaria.

Penginjilan yang dipakai oleh Yesus Kristus di tengah-tengah masyarakat yang memiliki permasalahan yang kompleks di bidang sosial, maupun budaya seperti yang dihadapi oleh perempuan Samaria dalam teks Injil Yohanes 4:1-42. Yesus menerobos kesenjangan itu dengan memberikan pemahaman baru bagi mereka bahwa hal yang terpenting ialah mendengar tentang Injil keselamatan. Pendekatan ini juga masih relevan bagi orang-orang percaya yang memiliki beban terhadap penginjilan. ${ }^{62}$

Harming memaparkan bahwa metode penginjilan semestinya disesuaikan dengan konteks budaya dan sosial, sehingga penginjilan dapat dilakukan dengan baik. Yesus melakukan penginjilan kepada perempuan Samaria menggunakan metode persahabatan dengan meminta tolong agar diberikan air, sekalipun orang Yahudi (Yesus Kristus) dan orang Samaria (perempuan) tidak bersahabat bahkan saling membenci. Yesus telah menunjukkan suatu kerendahan hati yang mendahului persahabatan. Harming juga memberikan laporan selanjutnya:

Hasil penelitian yang penulis lakukan terkait dengan Metode Penginjilan Yesus dalam Injil Yohanes 4:1-42, ada beberapa kesimpulan yaitu: Pertama, perjalanan Yesus melintasi Samaria ialah ingin mencari orang yang membutuhkan keselamatan, dimana orang Samaria merupakan suku yang tidak baik menurut orang Israel. Kedua, komunikasi Yesus dengan perempuan Samaria melalui persahabatan yang dibangun ketika percakapan mereka di tepi sumur. Ketiga, selain membangun persahabatan, juga melibatkan orang yang berpengaruh dalam lingkungan tersebut. Keempat, dalam kebudayaan Samaria dan orang Israel, terdapat perbedaan kebudayaan yang mengakibatkan pemahamanpemahaman yang keliru dalam mengerti kebenaran tentang Mesias. Dalam pemahaman

\footnotetext{
${ }^{61} \mathrm{https}: / /$ twitter.com/WorldHarvestInd Diakses tanggal 9 Mei 2019, jam 2:09pm

${ }^{62}$ Harming, Penginjilan Yesus dalam Injil Yohanes 4:1-42. Evangelikal: Jurnal Teologi Injili dan Pembinaan Warga Jemaat (online), Vol. 1, No. 2 (2017): Juli; 162. (https://journal.sttsimpson.ac.id/index.php/EJTI/issue/view/9) Diakses tanggal 9 Mei 2019, jam 05:42pm.
} 
tersebut, Yesus merekonstruksi ulang pemahaman yang keliru dari perempuan Samaria. Sebelum bertemu dengan Yesus, paradigma perempuan tersebut tentang konsep keselamatan bahwa Mesias yang dinantikan oleh orang Israel akan menyampaikan segala sesuatu kepada mereka, demikian juga konsep penyembahan kepada Allah dijelaskan yaitu orang Yahudi menyembah Allah di Yerusalem sedangkan orang Samaria menyembah Allah di Gunung Gerizim. Dalam percakapan tersebut, perempuan Samaria menyampaikan argumentasinya tentang konsep pemahamannya akan keselamatan didasarkan pada kebiasaan dan budaya orang Israel pada umumnya. ${ }^{63}$

Yesus Kristus telah memberikan contoh penginjilan lintas budaya atau mutikultural terhadap perempuan Samaria, suatu keteladan yang patut ditiru oleh penginjil di masa kini. Yesus telah berhasil melakukan penginjilan terhadap orang yang berbeda budaya dengan diri-Nya. Model persahabatan ini dapat dijadikan sebagai salah satu metode untuk melakukan penginjilan guna menjangkau jiwa-jiwa bagi Yesus Kristus.

\section{Kesimpulan}

Perintah Yesus Kristus untuk mengabarkan keselamatan ke seluruh dunia atau kepada setiap orang sangatlah mungkin untuk dilakukan. Tantangan atau hambatan pasti ada, namun tidak akan membuat semangat penginjilan "redup." Tekanan yang dialami justru akan membuat setiap penginjil mengandalkan Tuhan sembari mengupayakan kreativitas yang efektif untuk menginjil. Peneliti telah memaparkan setidaknya ada 6 (enam) model penginjilan, yakni: model penginjilan interpersonal, model penginjilan pribadi, model penginjilan massal, model penginjilan pelayanan media, model penginjilan pelayanan sosial dan model penginjilan persahabatan. Keenam model tersebut merupakan model penginjilan terbaik, yang tentunya dapat digunakan sesuai kebutuhan, dengan tujuan mulia yakni menuntun setiap orang menerima Yesus Kristus secara pribadi untuk memperoleh kepastian hidup kekal.

\section{REFERENSI}

BibleWork7, LLC. 3800 Colley Avenue 6158 Norfolk, VA 23508.

Carson, D. A. The Gospel According to Jhon. England: Inter-Varsity Press and Grand Rapids: William B. Eerdmans Publishing, 1991.

Doherty, Sam. Mengapa Menginjili Anak-anak? Jakarta: Lembaga Penginjilan Anak-anak Indonesia, t. t.

Ellis, D. W. Metode Penginjilan: Istimewa Tepat Guna Bagi Penginjil Awam Praktis dan Taktis. Jakarta: Yayasan Komunikasi Bina Kasih/OMF, 1999.

Foulkes, F. Ensklopedi Alkitab Masa Kini. Jilid 2. Jakarta: Yayasan Komunikasi Bina Kasih/OMF, 2000.

Gordon, M. R. Ensiklopedi Alkitab Masa Kini. Jilid 1. Diterjemahkan oleh Broto Semedi. Jakarta: Yayasan Komunikasi Bina Kasih/OMF, 2000.

Guthrie, Donald. Tafsiran Alkitab Masa Kini. Jilid 3. Diterjemahkan oleh W. B. Sijabat. Jakarta: Yayasan Komunikasi Bina Kasih/OMF, 1999.

Hagelberg, Dave. Tafsiran Injil Yohanes (Pasal 1-5) Dari Bahasa Yunani. Yogyakarta: Yayasan ANDI, 1999.

\footnotetext{
${ }^{63}$ Ibid., 168. Diakses tanggal 9 Mei 2019, jam 05:51pm.
} 
Harming. Penginjilan Yesus dalam Injil Yohanes 4:1-42. Evangelikal: Jurnal Teologi Injili dan Pembinaan Warga Jemaat (online), Vol. 1, No. 2 (2017): Juli; 162.

(https://journal.sttsimpson.ac.id/index.php/EJTI/issue/view/9)

Hasan Sutanto, Perjanjian Baru Interlinear: Yunani-Indonesia dan Konkordansi Perjanjian Baru (Jakarta: Lembaga Alkitab Indonesia, 2004), 1:486.

Heath, Stanley. Penginjilan dan Pelayanan Pribadi. Surabaya: YAKIN, 1979.

https://twitter.com/WorldHarvestInd Diakses tanggal 9 Mei 2019, jam 2:09pm

Kalalo, Johny Christofel. Penginjilan "Mengasihi” Sistim Sokratik. Yogyakarta: Sekolah Tinggi Theologia Injili Indonesia, 2000.

Kennedy, D. James. Ledakan Penginjilan. Jakarta: IFTJ Jaffray Jakarta, t. t.

Lembaga Pelayanan Mahasiswa Indonesia. Empat Hukum Rohani. Jakarta: Lembaga Pelayanan Mahasiswa Indonesia, t. t.

Marantika, Chris. Doktrin Keselamatan dan Kehidupan Rohani. Yogyakarta: Iman Press, 2004.

Morris, Leon. The New International Commentary on the New Testament. Grand Rapids: William B. Eerdmans Publishing Company, 1971.

Nixon, R. E. Ensiklopedi Alkitab Masa Kini. Jilid 2. Jakarta: Yayasan Komunikasi Bina Kasih/OMF, 2000.

Octavianus, Steaven Analisis Penggunaan Aplikasi “yesHeis” Dalam Penginjilan Pribadi. Evangelikal: Jurnal Teologi Injili dan Pembinaan Warga Jemaat (online), Vol. 2, No. 1 (2018): Januari; 68. (https://journal.sttsimpson.ac.id/index.php/EJTI/issue/view/11)

Packer, J. I. Penginjilan dan Kedaulatan Allah. Surabaya: Momentum, 2003.

Peters, George W. Teologi Pertumbuhan Gereja. Diterjemahkan oleh Gandum Mas. Cetakan Pertama. Malang: Gandum Mas, 2002.

Stamps, Donald C. Editor Umum. Alkitab Penuntun Hidup Berkelimpahan. Diterjemahkan oleh Nugroho Hananiel. Disunting oleh Bertha Gaspersz. Malang: Gandum Mas, 1984.

Tanhidy, Jamin. Praktik Metode Penginjilan Pada Mata Kuliah Metode Penginjilan STT Simpson Ungaran. Evangelikal: Jurnal Teologi Injili dan Pembinaan Warga Jemaat (online), Vol. 1, No. 1 (2017): Januari; 49.

https://journal.sttsimpson.ac.id/index.php/EJTI/article/view/55/39)

Tomatala, Yakob. Penginjilan Masa Kini 2. Cetakan Pertama. Malang: Gandum Mas, 1998.

Travis, Ed. Kepemimpinan Gereja Masa Kini. Tangerang: Yayasan Damai Mulia, 2005.

William, Brother. Penginjilan Akhir Zaman. Diterjemahkan oleh Yeri Ekomunajat. Disunting oleh Eva Yunita. Yogyakarta: ANDI Offset, 2007. 